\title{
From smart growth to European spatial planning: a new paradigm for EU cohesion policy post-2020
}

\section{Eduardo Medeiros}

To cite this article: Eduardo Medeiros (2017) From smart growth to European spatial planning: a new paradigm for EU cohesion policy post-2020, European Planning Studies, 25:10, 1856-1875, DOI: $10.1080 / 09654313.2017 .1337729$

To link to this article: https://doi.org/10.1080/09654313.2017.1337729

曲 Published online: 09 Jun 2017.

Submit your article to this journal $\pi$

Џll Article views: 560

View Crossmark data \lceil

4 Citing articles: 3 View citing articles 


\title{
From smart growth to European spatial planning: a new paradigm for EU cohesion policy post-2020
}

\author{
Eduardo Medeiros
}

Centro de Estudos Geográficos (CEG), Institute of Geography and Spatial Planning (IGOT), Universidade de Lisboa, Lisboa, Portugal

\begin{abstract}
Formally initiated in 1989, European Union (EU) cohesion policy (ECP) has since passed through a series of metamorphoses, along its five programming periods, while becoming the most financed EU policy. As its name indicates, its initial goals were earmarked for promoting economic and social cohesion, following the intentions expressed in the Single European Act. Since then, from a policy strategy intervention point of view, ECP has shifted into a financial tool to promote investment for growth and jobs. In the meantime, European spatial planning (ESP), which had its debating pinnacle with the release of the European Spatial Development Perspective, by 1999, has declined in interest and narrowed into a novel notion of Territorial Cohesion. In this challenging context, this article analyses the implementation and main impacts of ECP and proposes a new strategic paradigm, built around a novel 'ESP' vision, backed by the main pillars and dimensions of territorial development and cohesion. More particularly, we suggest that the current rationale for a smart, sustainable and inclusive growth could instead fuel an alternative strategic design based on a cohesive and sustainable development vision: green economy, balanced territory, good governance and social cohesion.
\end{abstract}

\section{ARTICLE HISTORY}

Received 9 April 2017

Revised 23 May 2017

Accepted 26 May 2017

\section{KEYWORDS}

EU cohesion policy; territorial cohesion; European spatial planning; territorial cooperation; territorial development

\section{Introduction}

The European Union (EU) Regional Policy, also known as EU Cohesion Policy (ECP), is presently the EU's main investment policy, as highlighted in its official website. ${ }^{1}$ Moreover, its importance for the EU's overall political agenda goes beyond the mere financial allocation aspects, as its holistic policy thematic character and sectoral scope make it a perfect 'tool' for fomenting territorial development and cohesion processes, in view of the goals expressed in the EU Treaty: promote economic, social and territorial cohesion, and solidarity amongst Member States (Article 3).

In the same way, directly or indirectly, ECP has been positively impacting spatial planning instruments at all territorial levels (urban, local, regional, national and transnational). These impacts are not only seen in the creation of new spatial planning policy instruments 
and regulations/legislation, within EU Member States, as 'mandatory regulative tools' to access available EU funding, but also as fundamental 'policy strategic design tools' for increasing place-based, integrated and more efficient policy implementation processes, for instance in the ECP Regional Operational Programmes.

Indeed, despite the fact that European Spatial Planning (ESP) is not a formal competence of the EU (see Faludi, 2006; Ferrão, 2003, 2010), that does not necessarily translate into its effective influence on the patterns of the EU's territorial development, and also on the implementation of some EU sectoral policies. Clearly, as Dühr, Colomb, and Nadin (2010, p. xix) remember, it is undeniable that the EU has become an important actor for influencing spatial planning decisions and shaping the spatial development of the European territory'.

Such a claim becomes most evident when reading the expressed goals of national and regional spatial planning policies which, in several cases, tend to follow the goals expressed in ESP 'agenda setting' documents, such as the European Spatial Development Perspective (ESDP - EC, 1999a), and the two Territorial Agendas (Territorial Agenda, 2007, 2011). This is, for instance, evident in the incorporation of the EU goal of achieving polycentric development as a counterpoint to existing concentration in the 'Blue Banana' (see Faludi, 2014), and a more sustainable and cohesive development process, into national and regional spatial plans (see Medeiros, 2014c).

In this context, this article discusses the potential positive effects of placing ESP at the heart of ECP strategic goals, guidelines and principles, to fuel the clamour for a cohesive and development post-2020 EU policy paradigm, rather than the present (2014-2020) narrowed vision of 'growth'. As such, along the following lines, we propose to answer the following guiding research question: How can ESP strategies act as a catalyst to implement a post-2020 ECP paradigm for territorial development and cohesion?

For clarity's sake, in this article we see eye to eye with Faludi $(2010$, p. 3) when he understands ESP as 'the mode of operation in strategic spatial planning', notably by 'appreciating a territory relevant to solving one or more issues and formulating appropriate joint spatial strategies or visions'. In a more simplified way, we propose a definition of ESP as a 'strategic spatial plan for promoting territorial development and cohesion at the EU level, with a view to anticipating transnational territorial changes, tackling transnational territorial needs, and promoting transnational territorial potentials, within the EU territory and adjacent countries'.

In turn, ECP is presently regarded as the main EU investment policy tool for supporting regional and national growth - by stimulating job creation, competitiveness, economic growth, improved quality of life and sustainable development, following the Europe 2020 strategy goals - and territorial cooperation processes (cross-border, transnational and interregional). Instead, we regard ECP as the main EU policy tool to attain the goal expressed in Article 174 of the EU Treaty: promote the EU overall harmonious development by developing and pursuing its actions, leading to the strengthening of its economic, social and territorial cohesion.

By embracing two widely discussed topics available in the academic literature (ECP and ESP), this article aims at contributing mostly to highlight the potential gains of promoting European Territorial Development and Cohesion, relating both in a more strategic and profound manner. For that, the paper is organized in three different sections and a conclusion. The next section briefly discusses the evolution of the ECP strategic visions and 
their adaptations to specific socio-economic and political contexts, while critically debating the present focus on a 'growth and jobs' paradigm. The next section outlines the potential advantages of replacing the EU mainstream policy agendas, such as the Lisbon and the Europe 2020, by an EU ESP-based policy agenda, in order to place transnational development at the core of EU policy design and implementation. The last section presents a concrete vision for placing ESP at the core of the ECP strategic design, while proposing concrete policy goals, targets, guidelines and principles for a post-2020 phase of this policy.

From a methodological standpoint, this article elaborates on two widely holistic concepts: territorial development and territorial cohesion, in order to propose an alternative conceptual vision for a post-2020 ECP. Moreover, it makes use of a wide set of theoretical contributions, both on ESP and on ECP academic discussions. Furthermore, many of its proposals and conclusions are based on more than 20 years of experience in analysing and evaluating ECP-related programmes and projects, and consequent contacts with a myriad of politicians, officials and practitioners, from which we obtained essential knowledge on the operational aspects and impacts of this policy in different European countries and regions.

\section{Growth or cohesion? A reflection on the true purpose(s) of ECP}

ECP was elaborated to cope with the very large disparities in wealth amongst EU regions and countries (Molle, 2007). In view of the above, the main goal of ECP was to promote economic convergence by assisting less favoured regions, namely, by means of investments funded by EU Structural and Cohesion Funds (Begg, 2010). From a formal perspective, however, 'on 24 June 1988, the Council agreed on a regulation which put existing EU funds into the context of "economic and social cohesion", a term which the Single European Act had introduced two years earlier' (EC, 2008a, p. 1). In this stance, ECP was initially launched as a 'socio-economic cohesion' vehicle, and not as a 'growth and investment' funding policy. Notwithstanding, since then, ECP went through significant changes, in its strategic, management, control and audit approaches (Bauer, 2008; Davies \& Polverari, 2011; Kassim, 2008).

Ultimately, ECP has been shaped by the adoption of several EU mainstream political agendas/strategies, such as the 'Lisbon Strategy', the 'Gothenburg Agenda' and the 'Europe 2020 Strategy', which respectively (i) placed a focus on growth, employment and competitiveness; (ii) reinforced the vision for a sustainable development strategy and (iii) promoted a paradigm for a smart, sustainable and inclusive growth.

Again, the ECP strategy rationale was greatly influenced by the entry into force of the Maastricht, Amsterdam and Lisbon Treaties, which respectively led to: (i) the introduction of the Cohesion Fund; (ii) the focus on employment and social aspects of development and (iii) the inclusion of the goal of territorial cohesion, alongside the social and economic cohesion goals. Finally, the successive accession of new Member States (Sweden, Finland and Austria in 1995; Malta, Cyprus, Estonia, Latvia, Lithuania, Poland, Czech Republic, Slovakia, Slovenia and Hungary in 2004; Bulgaria and Romania in 2007 and Croatia in 2013) led to a significant rise of sparsely populated and less-developed areas within the EU (Medeiros, 2016c).

All in all, these events induced successive adaptations in the 'strategic rationale and governance architecture' of ECP, with three distinct phases: (i) the 'pre-Lisbon Strategy' 
phase (1989-1999), marked by a 'socio-economic convergence' strategic rationale; (ii) the 'Lisbonization' phase (2000-2013), which reinforced the 'growth and employment paradigm', while triggering a shift towards an emphasis on innovation and (iii) the 'Europe 2020' phase (2014-2020), where the 'growth' (smart, sustainable and inclusive) rationale took a primary role, while paradoxically a wider attention was given to the 'territorial dimension' of ECP.

In sum, according to Mendez (2011), the 'Lisbonization' of ECP brought about several procedural innovations, mainly related to the governance model, with a view to promoting accountability and aligning EU and national goals through national plans. On its turn, Begg (2010) remembers that, from 2000 onwards, a wider integration of EU structural funds was pursued, together with substantial reorientation of the available ECP funding to the new Member States. However, he also notes that, from a strategic policy rationale, this new era of ECP saw a gaining ascendency of competitiveness over the solidarity or equity paradigm. This resulted from increasing globalization pressures and the adoption of the Lisbon strategy guidelines.

However, according to Mendez (2013), the most significant makeover of ECP took place during the post-2013 proposals, with a view to (i) spread its support more evenly across the EU; (ii) pursue a more integrated territorial development approach across all shared management funds; (iii) focus expenditure within Europe 2020 priorities and (iv) promote more rigorous target setting and conditionalities (see Bachtler \& Ferry, 2015), amongst others. Likewise, Begg (2010, p. 78) concludes that, by then, a considerable attention was placed 'on the "territorial" dimension of cohesion, which has connotations of spatial planning at the level of the EU as a whole'. Hence, while the 'growth and competitiveness' paradigm gained ground within the ECP strategic design, the same happened with the awareness of promotion of a more 'integrated and territorial approach' within ECP project design and implementation.

By implication, from a political narrative perspective on its strategic principles, there are some evidences which indicate this gradual shift into a more neo-liberal agenda and a gradual erosion of the ECP's foundational principles (see Begg, 2010; Mendez, 2013), namely, in the two most recent programming periods. Indeed, for the 2014-2010 programming cycle, the 'growth and jobs' narrative was translated into the main goal of ECP. At the same time, the translation of the Europe 2020 objectives into place-based frameworks was considered insufficient, namely by the Committee of the Regions (CoR, 2009), despite the spotlight placed on 'smart specialization' strategies (McCann \& Ortega-Argilés, 2015), which aim to help European regions to focus on their specific strengths, in order to increase local economic and cultural potentials (Solly, 2016, p. 194).

In sum, faced with mounting globalization processes and neo-liberalist political agendas, ECP has gradually shifted its strategic design from the initial goals of achieving socio-economic cohesion to the present goals of fomenting growth and jobs. However, from a funding distribution perspective, ECP have always kept an 'EU territorial cohesion perspective', by channelling the bulk of the financing into the less-developed regions of the EU (EC, 2014) and by supporting all dimensions of territorial cohesion (see Medeiros, 2016d). A more awkward plea is the growing support to territorial integration and place-based processes supported by recent ECP 'related funds' regulations. By implication, ECP's intrinsic purposes to support 'cohesion policy processes' have not been erased from 
its core. And this, in our view, provides the necessary fertile ground to place ESP as a strategic design paradigm for future potential ECP programming periods.

\section{Spatial planning as a (re)trigger for territorial development and cohesion visions for an uncertain EU}

\subsection{ESP towards territorial cohesion}

For the past years, ESP has been emerging not only as a response to address EU real problems and needs, but also as an instrument 'to help reconcile the potentially contradictory core EU objectives of economic competitiveness, social cohesion and sustainable development' (Dühr et al., 2010, p. 5). At the same time, a rich vein of theoretical reasoning invokes the limitations associated with the 'economic growth and competitiveness' vision for policy implementation, vis-à-vis a more broad and complete vision of 'territorial development and cohesion'. More particularly, Stutz and Warf (2012, p. 368) advocate that in conventional usage, development is a synonym for economic growth. But growth is not development (...)', as the latter is a multidimensional concept, thus going beyond economic competitiveness, while encompassing concerns over social, environmental and democratic-related values.

One prevailing vision of development relates it with the necessary 'change that is intended to lead to the betterment of people and places around the globe' (Potter, Binns, Elliott, \& Smith, 2008, p. 6). Moreover, the idea of development carries connotations with the notion of progress (Thomas, 2000), and this, in turn, led the United Nations to state that 'human development is about much more than the rise or fall of national incomes' (UNDP, 2001, p. 9). Likewise, the notion of territorial cohesion is multidimensional (Faludi, 2004; Medeiros, 2016d), and only differs from the concept of territorial development, as the latter can be attained in all regions (positive change in most development dimensions) at the same time, while the former cannot (positive change is higher in the already most developed region of a given territory).

As such, in our understanding, ECP's ultimate goal should focus on achieving 'territorial cohesion', rather than 'growth'. As expressed in Article 3 of the EU Treaty, the EU 'shall promote economic, social and territorial cohesion and solidarity among Member States' (EU, 2010, p. 17). More acutely, Article 174 states that in order to promote its overall harmonious development, the Union shall develop and pursue its actions leading to the strengthening of its economic, social and territorial cohesion' (EU, 2010, p. 127). Drawing upon this EU mainstream political goal, ECP can be regarded as a concrete political tool to achieve it. So how can an 'ESP-based strategy' be more effective in its strategic design than the mainstream EU political agendas, such as the Lisbon and Europe $2020 \mathrm{EU}$ strategies? To answer this question, we firstly need to better differentiate both.

\subsection{Advantages of ESP over EU mainstream strategies}

In simple terms and according to the EU Compendium of Spatial Planning Systems and Policies (EC, 1997, p. 24), spatial planning

refers to the methods used largely by public sector to influence the future distribution of activities in space. It is undertaken with the aims of creating a more rational territorial 
organization of land uses and linkages between them, to balance demands for development with the need to protect the environment, and to achieve social and economic objectives. Spatial planning embraces measures to co-ordinate spatial impacts of other sectoral policies, to achieve a more even distribution of economic development between regions that would otherwise be created by marked forces, and to regulate the conversion of land and property uses $[\ldots]$.

As seen, this mid-1990s notion of spatial planning encompasses both (i) 'policy strategic planning' on the need to plan economic, social and environmental aspects of policies, in order to achieve a more harmonized and sustainable distribution of activities and (ii) 'legislation regulative planning' processes, associated to the need to regulate land uses (see Albrechts, 2006; Davoudi \& Strange, 2007; Kidd \& Shaw, 2013; Morphet, 2011). Similarly, the mentioned EU Compendium of Spatial Planning highlighted another crucial aspect to ESP when it recognized that 'spatial planning encompasses elements of national and transnational planning, regional policy, and regional planning (...)' (EC, 1997, p. 24).

In much the same way, the EU mainstream policy agendas (Lisbon and Europe 2020) define a set of goals for developing the EU territory. However, both concentrate their action on aspects related to the triad 'economy + society + environment', while lacking a more holistic and territorial approach for development, thus the need for the publication of the two Territorial Agendas (Territorial Agenda, 2007, 2011). A commonly held view regards those agendas as an expansion of the ESDP (Moreno, 2012, p. 351). Taken all together, comparably, an ESP strategy presents the following advantages over the mentioned EU policy strategic strategies:

- It adds a territorial dimension to policy strategic planning, by going beyond the economy-society-environment strategic development triad vision.

- It provides a place-based approach by identifying the territorial needs and potentials of the EU territory at all territorial levels: local, regional, national, transnational and European.

- It offers a means to better interconnect and integrate existing regional, national and translational spatial planning strategies (read macro-regional strategies - see Medeiros, 2013).

- It opens an avenue to make a more effective use of the work done by the European Spatial Planning Observatory Network (ESPON), namely in unveiling the EU territory needs, potentials and challenges.

- It elevates the role of Territorial Impact Assessment (TIA) procedures as an EU principal policy evaluation process.

- It contributes to elevate the goals of promoting territorial development and territorial cohesion, instead of a social, economic and green growth paradigm.

In the same way, Dühr et al. (2010, p. 11) identify a set of arguments both for and against a European dimension of spatial planning. On the positive side, they argue that ESP (i) is required to coordinate EU policies and actions which have spatial dimensions and impacts; (ii) is needed to develop and implement EU policy goals of promoting balanced spatial development; (iii) is needed to engage on new forms of transnational territorial governance, which deals more effectively with functional regions; (iv) can prevent 
damaging competition and free-riders on improving environmental conditions or economic competitiveness; ( $\mathrm{v}$ ) is required to avoid distortions to the single market provoked by varying approaches to spatial planning; (vi) can help to resolve the competing objectives of economic competitiveness, social cohesion and environmental sustainability and (vii) can provide a model of democratic and socially led spatial organization for existing and new Member States, and neighbouring countries.

Alternatively, for Kunzmann (2006, p. 58), spatial planning is instrumental for reinforcing territorial governance processes, namely by (i) providing spatial knowledge to policymakers; (ii) preparing the ground and showing directions for infrastructure development; (iii) strengthening local and regional institutions; and (iv) involving citizens in regional communication processes. In this domain, we can detect a fundamental relation between the advantages of implementing ESP processes and EU multilevel governance which characterizes ECP.

\subsection{ESP: an informal crystallization path through territorial cooperation?}

The publication of 'spatial planning visions' for the EU territory is far from being recent, as in 1983 the EU adopted the European Regional/Spatial Planning Charter, in Torremolinos (Faludi, 2010; Medeiros, 2014c). In the following, and while the ESP mother document (ESDP) was not released, two other related ESP documents were published: (i) the Europe 2000 (EC, 1991) and (ii) the Europe 2000+ (EC, 1994). Curiously, by now, no update was provided for the 'old ESDP', despite the successive EU territorial enlargements and the emergence of novel territorial development challenges (economic and migration crisis, climate changes, etc.). Again, the fact the ESP is not regarded as an EU formal competence can explain a non-update of the ESDP. Even so, since the publication of this document, the idea of an ESP was translated into an EU vison of Territorial Cohesion (Faludi, 2006), followed by the discussion of this notion in the Second (EC, 2001a ) and Third Cohesion (EC, 2004) reports.

But more importantly, the formation of the ESPON, in 2002, and the consequent work on analysing territorial trends in the EU territory, can be regarded a crystallization process of a 'non-formal ESP platform' within the EU, as it prompted visibility to a myriad of territorial trends within the EU territory. Moreover, it has allowed for the production of several studies which relate to ECP interventions and their impacts (ESPON ATLAS, 2006, 2014). In the end, the ESPON programme has been given its contribution to better understand the effects of EU-funded policies and to highlight the need to promote a wider territorial integration process in EU policy implementation, based on an appreciation of the territory and its potentials (Faludi, 2010, pp. 2-3). In sum, for Waterhout (2008, p. 9), the current ESP process 'centres around four pillars: the ESDP, the INTERREG programme, the ESPON programme and, the most recent achievement, the Territorial Agendas of the EU'.

However, the controversy surrounding the need for ESP is ongoing. As Faludi (2010, p. 1) concludes, its requisite for the EU depends on one's view of planning and the EU itself. Understandably, for European spatial planners

the European dimension of spatial planning arises from a recognized and growing need for coordination of spatial development trends and EU spatial policy across policy sectors, across 
levels of government from the EU to the local level, and across national borders. (Dühr et al., 2010, pp. 4-5)

In the end, for anyone involved in territorial analysis related to EU cross-border and transnational territorial processes, normally associated with the EU INTERREG programmes, it is not difficult to understand the need for an EU transnational approach to address concrete needs and make the most of out of EU transnational territorial potentials. For these and other reasons, 'despite this apparent lack of competence, there has been a lot of activity on spatial planning at the EU level involving the member states working "intergovernmentally" with support from the European Commission' (Dühr et al., 2010, p. 15).

Another 'positive impact' from the work carried out by the elaboration of the ESDP was the continuous institutionalization of spatial planning processes across several EU Member States, as Waterhout (2008) demonstrates in his seminal work on ESP, despite its minimal influence at the EU level. The same author reminds us also of the importance of the INTERREG II-C and the following INTERREG III-B (transnational cooperation) programmes, as a concrete test-ground platform for applying the ESDP messages. This conclusion peps out the idea that ESP and ECP have been related for quite a long period, one way or the other, namely by the operationalization of European Territorial Cooperation (ETC) processes. However, as Kunzmann (2006, p. 57) reiterates, ESP is still a weak policy filed in the EU, and 'much of the opposition to spatial planning as an important public sector action field is based on prejudice, lack of information, or just unwillingness to accept the leading role of the public sector on territorial development'.

Nevertheless, it would appear reasonable to surmise that 'spatial planning strategies operating at multiple scales have in the last decade come to be viewed as key policy instruments for effective territorial governance' (Walsh, 2014, p. 306). There are, however, positive developments regarding the effects of ECP in promoting a more integrated approach to policy design and policy-making. These have sparked not only transnational and macro-regional planning processes (Medeiros, 2013), but also some attempts to promote cross-border spatial planning processes, which are still relatively new in the EU, despite being one of the main challenges for the EU border regions development process (Durand, 2014; Medeiros, 2014d). As Faludi (2014, p. 165) concludes, despite the reluctance from the European Commission (EC) in activating a shared competence for territorial cohesion and ESP, the 'INTERREG continues to give planners experience in working on cross-border, transnational and European scales, and ESPON too may become a site for this progressive Europeanisation of planning'.

\subsection{ESP: consolidating a change from a result-oriented to an impact-oriented ECP}

Far from signalling the end of ESP, the EU territorial cohesion narrative gained momentum within the EU political agenda, and culminated with the inclusion of this multidimensional and holistic concept in the Lisbon Treaty. Indeed, as Molle (2007, p. 84) points out, the operational concept of territorial cohesion should be found in spatial planning-related documents. On another perspective, territorial cohesion has rapidly gained currency within the EU political meanders, in order to avoid any association with regulative land-use planning (Faludi, 2010, p. 1). By way of illustration, the same author proclaims 
that like spatial planning, territorial cohesion policy is about integrating policies with a spatial impact'.

To that degree, ECP is spread out to all EU (and some non-EU) regions. However, its effects vary from Member State to Member State and from region to region. For the most part, its territorial impacts have been more positive in less-developed Member States (see Medeiros, 2014a, 2014b, 2016a, 2016b), as ECP funding has remained concentrated in less-developed regions (62\% from 1989 until 2020 - see EC, 2014, p. 187). For this, and many other reasons, the ability to prove ECP's effectiveness and value for money is far from being consensual (Bachtler, Polverani, Oraz, Clement, \& Tödtling-sch]onhoffer, 2009; Polverani, 2016; Rodriguez-Pose \& Fratesi, 2004). This includes the assessment of its impacts in all territorial development domains, and its dependency on the quality of government and governance systems, amongst other aspects.

From the onset, ECP has institutionalized policy evaluation mechanisms, in order to unveil its main outcomes, results and impacts (see EC, 1999b). Nevertheless, the resultorientation approach has been slow to catch on. For that matter, the 2014-2020 regulations included a set of new obligations intended to improve policy results-orientation, both at the programme design and implementation phases (Polverani, 2016, p. 59). Alongside, the degree of policy accountability has also been increasing over time, with more responsibilities being shared by the EC with the Member States, namely in budget implementation (Davies \& Polverari, 2011). Even so, some allude to the weak EU control mechanisms (Blom-Hansen, 2005).

However, if there is one aspect in which the ESPON programme has forged new horizons for EU policy implementation, it was in its contribution to the elaboration of different methods of TIA policy evaluation procedures, despite their excessive simplicity in view of the need to properly evaluate the impacts of policies/programmes/projects (Medeiros, 2016e). In fact, the increasing attempts to promote TIA procedures have been borrowed from the tradition of spatial planning in certain European countries (Molle, 2007, p. 110). Again, in our perspective, the adoption of an ESP policy strategy vision, which guides the application of EU funding, would gain from replacing the ongoing 'result-oriented' paradigm with a more robust 'impact-oriented' one for EU policy evaluation processes.

\section{A synthetic spatial planning strategic vision for the EU post-2020}

In the previous sections, we presented a case to place ESP at the heart of EU strategic development and cohesion visions for the post-2020 period. This section takes this idea a bit further, by presenting a summarized ESP strategic vision, with which EU policies, and namely ECP, should align with. As expected, following from the above discussions, this proposed strategic vision undercuts the common assumption that the goal of EU policies is ultimately to promote 'territorial cohesion' and 'territorial development', and not 'growth'. Running parallel to this rationale, we propose a 'one goal - four targets' strategy, encompassing fundamental dimensions and respective elements of territorial cohesion and territorial development: (i) green economy, (ii) balanced territory, (iii) good governance and (iv) social cohesion (Figure 1).

Drawing on a distinction with the EUROPE 2020 strategy for smart, sustainable and inclusive growth, this proposed strategy elevates the notions of development and cohesion, vis-à-vis the narrow notion of 'growth' - thus (re)introducing the initial goals of the ECP, 


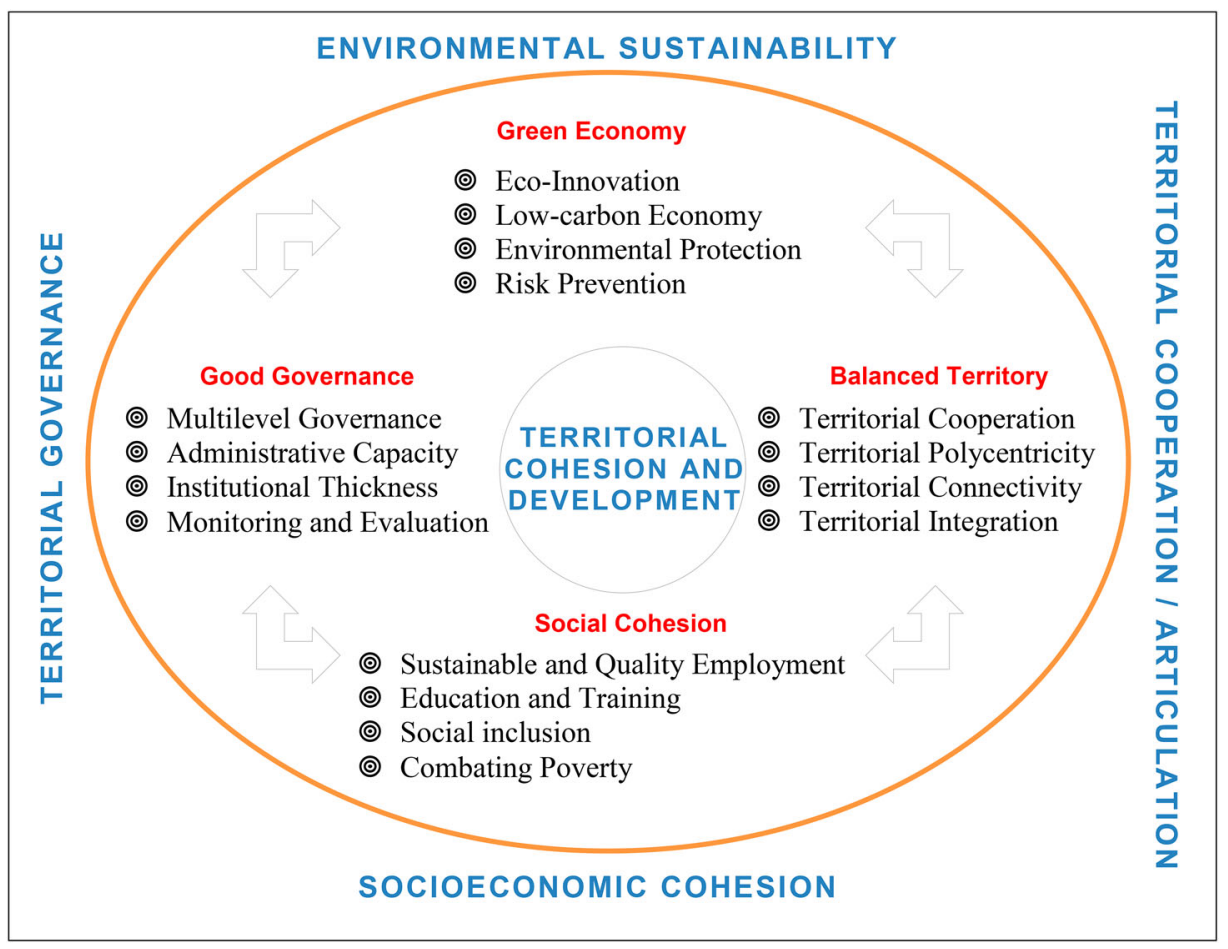

Figure 1. ECP post-2020 strategy: one goal, four targets.

while including a clear territorial dimension to an EU strategic vision, which was absent from the EUROPE 2020.

As expected, there would be a wealth of implications for a post-2020 ECP following the adoption of an ESP strategic vision for a renovated EU policy agenda. More acutely, the existing 11 thematic objectives for ECP would be eliminated, as they contradict the place-based and smart specialization rationale of policy implementation. On top of this, the present ECP main goals (two) of promoting 'growth and jobs' and 'territorial cooperation' would be replaced by one main goal: 'achieving territorial development and cohesion'. At the same time, the ETC goal would be elevated to a wider role (both strategically and financially) within this new territorial-driven ECP implementation approach (Table 1 and Figure 2). When contemplating these changes, we are not defending an emerging idea in which ECP funding should merge with the Juncker Plan, thus ceasing the grants provisions altogether and replacing them with loan guarantees so as to achieve more leverage. Instead, we propose the implementation of transnational

Table 1. Financial distribution proposal for ECP post-2020 per territorial level.

\begin{tabular}{lll}
\hline Territorial level & $\%$ & \multicolumn{1}{c}{ Programme/projects } \\
\hline Transnational & 40 & Large-impact projects (LIPS) + INTERREG B \\
Cross-border & 15 & INTERREG-A \\
National & 15 & Sectoral Operational Programmes \\
Regional & 15 & Regional Operational Programmes \\
Urban & 15 & Urban Development + INTERREG Europe \\
\hline
\end{tabular}




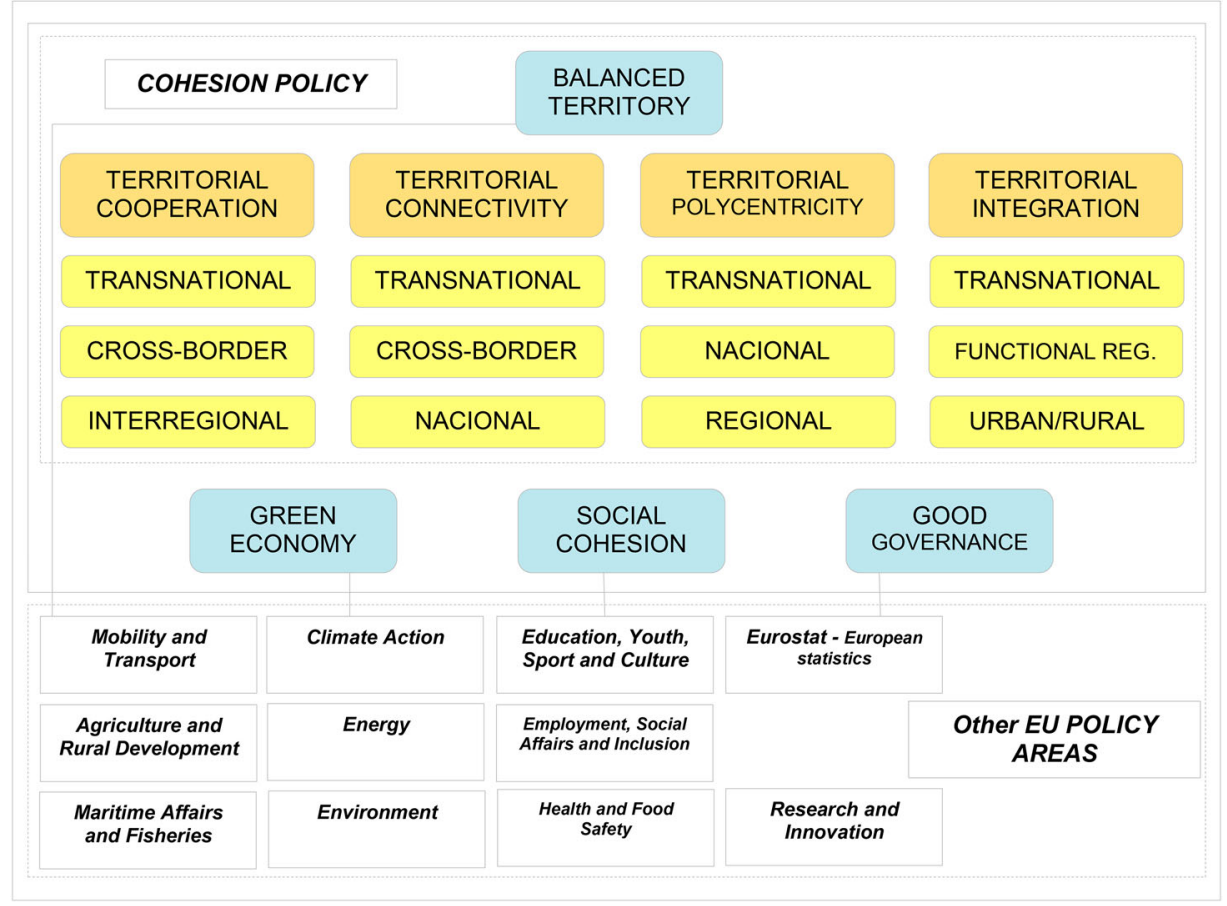

Figure 2. ECP territorial-driven strategy 2021-2026.

development/cohesion visions for the EU supported by ESP strategies. In other words, we propose a redesign of ECP which does not affect the way the financial allocations work presently. Rather, it only redefines its strategic guidelines while placing an emphasis on ESP processes, and the distribution of funding.

In sum, we propose that a post-2020 ECP is built upon an ESP transnational development approach, thus placing the present transnational and cross-border programmes at the heart of this policy. Ultimately, the related territorial cooperation projects/programmes should be based on large-impact transnational and cross-border projects with the goal to promote (i) a green economy; (ii) a balanced EU territory; (iii) good governance practices and (iv) social cohesion. At the same time, the process of cross-border cooperation would be fundamentally centred in (i) reducing the persistent barriers posed by the presence of administrative boundaries; (ii) valorizing the territorial capital of the border region and (iii) implementing cross-border planning strategies (Medeiros, 2017).

As regards the ECP principles and guidelines for the post-2020 period, for the most part we suggest the keeping of the existing ones. Beyond this, we propose a new set of principles and guidelines (Table 2) with a view to bring forward and solidify ESP as a cornerstone for ECP design and implementation, and also to elevate TIA procedures as a mainstream policy for ex ante, mid-term and ex post evaluation procedures. Also important, from our understanding, is the need to establish a financially independent monitoring/evaluation structure for EU-funded projects/programmes/policies, as opposed to current practices where policies/programmes/projects finance their own monitoring/evaluation 
Table 2. ECP post-2020 guidelines and principles.

Keep original principles

Add new principles

- Focusing on the poorest and most backward regions

- Multi-annual programming

- Strategic orientation of investments

- Involvement of regional and local partners - partnership

- Subsidiarity + concentration + additionality

Keep original guidelines Add new guidelines

- Focus on integrated territorial investments

- Focus on community led local development

- Sustainable urban development
- Strategic territorial planning: EU/transnational/cross-border

- Independency: monitoring/policy evaluation

- Focus in impacts: TIA

- Place based: tailor made to territorial needs/potentials

reports. The main idea is to improve the transparency and quality of EU policies evaluation procedures.

Such EU policy territorial integrated approaches, arising from a wider translational planning focus, would require, for instance (i) the concentration of funding in less-developed regions' anchor urban centres (Figure 3), in order to promote a more balanced and polycentric territory, in a more efficient way; (ii) the concentration of investments on tapping transnational renewable energy potentials, with a view to promoting a more green and sustainable EU territory (Figure 4); (iii) the support to a better governed territory, by focusing attention on transnational areas characterized by low levels of good

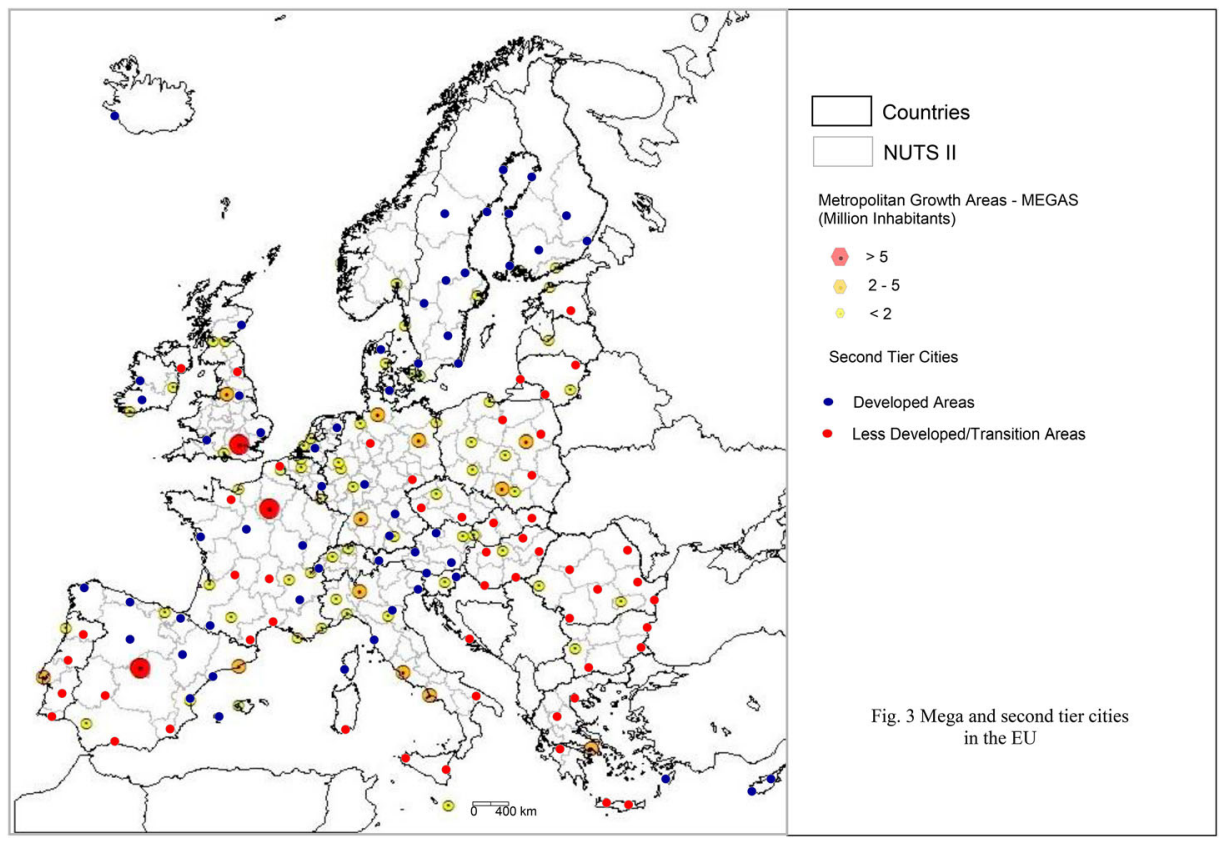

Figure 3. Mega- and second-tier cities in the EU. 


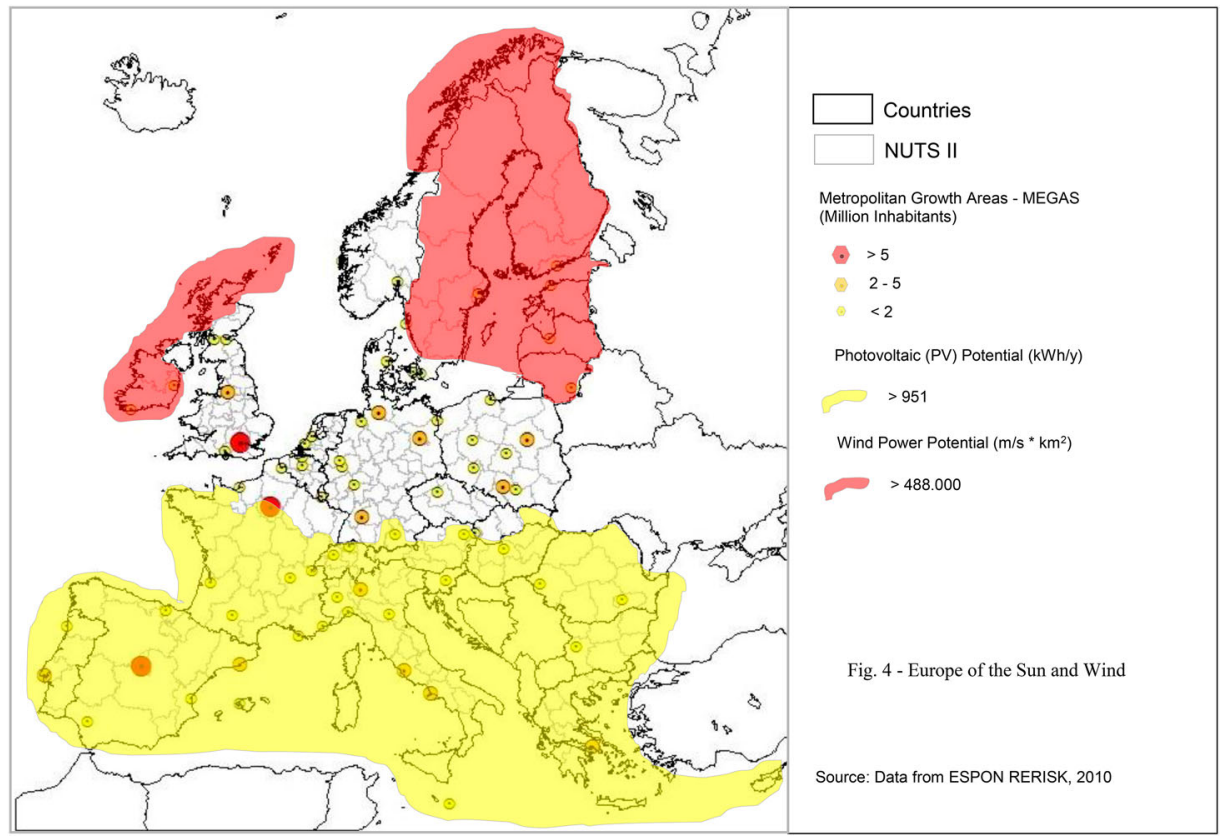

Figure 4. Europe of the sun and wind.

governance/government (Figure 5) and (iv) the attention to a more socially inclusive territory, as social exclusion and poverty continue to affect large parts the EU territory (Figure 6).

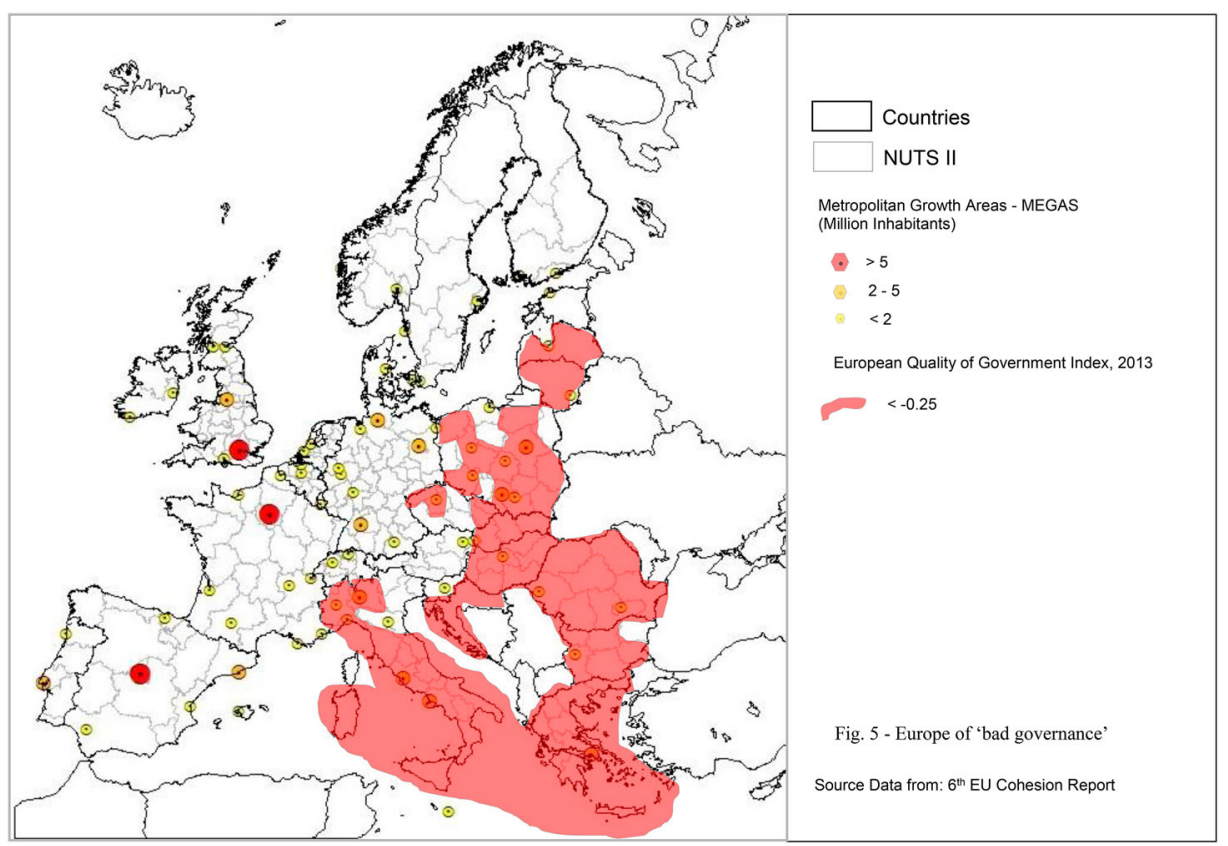

Figure 5. Europe of 'bad governance'. 


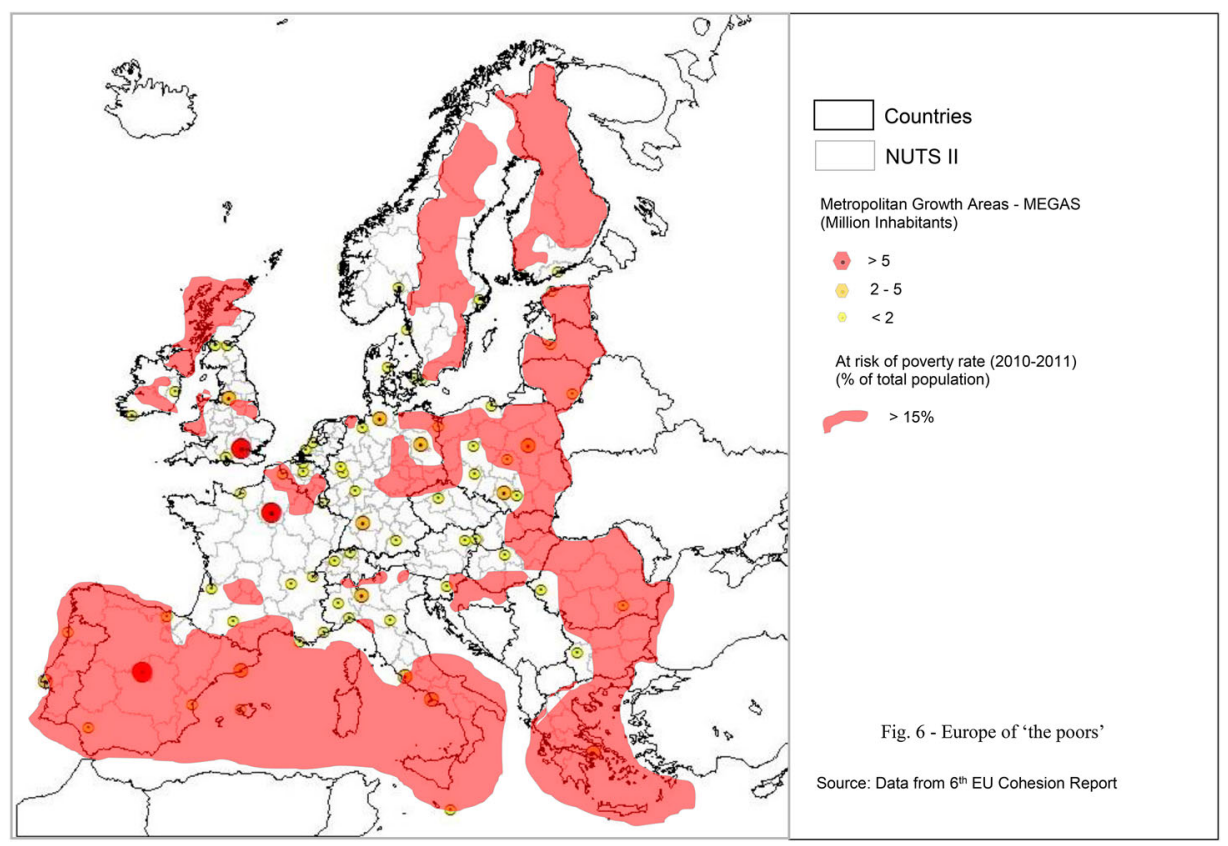

Figure 6. Europe of 'the poors'.

In the end, this proposed post-2020 ECP strategic vision, sustained by a projected ESP strategy development vision, is expected to place the EU territorial transnational development and integration approach at the forefront of EU policy-making, while tacking, in a more effective and efficient way, the fundamental pillars to achieving territorial cohesion. Such an emphasis on ESP also intends to spark and consolidate a '60-year EU project' which brought a new era of peace and prosperity to Europe - by solidifying a unique system of multilevel governance. Furthermore, as stated in the White Paper on European Governance, the EU should refocus its policies in order to identify more clearly its longterm objectives in all areas of development (EC, 2001b). And this goes in line with the proposed alignment of a post-2020 ECP with an ESP strategy.

In the previous section, we alluded to several advantages of the adoption of ESP to tackle a myriad of powerful challenges facing the EU territorial development. In this regard, the available literature on EU future challenges (EC, 2008b) and territorial trends (ESPON ATLAS, 2014) support our claims of the advantages of planning ahead and acting with an ESP vision to mitigate future challenges. Moreover, these and many other documents produced under the ESPON auspices are clear in demonstrating that the most important challenges and untapped territorial potentials have a clear transnational character.

More precisely, when it comes to the main challenges that will impact on the EU territorial development over the coming year, such reports highlight, for the most part, transnational issues, such as demographic ageing, climate changes and globalization-related impacts, thus 'making the European dimension ever more important in boosting knowledge, mobility, competitiveness and innovation', since 'regional disparities in economic output and income in the European Union are far more extreme than in similar economies 
such as the US or Japan' (EC, 2008b, pp. 5-6). Moreover, the EU is characterized by the presence of relatively geographically small nations, with open economies, which would gain from strengthening potential synergies with their EU partners, to solve key development challenges.

Another solid argument for this novel transnational approach, which we propose for the post-2020 ECP phase, comes from the gains deriving from the long-term experiences collected in implementing ETC processes in Europe, and more particularly in the EU territory. In fact, such experiences have been consolidated by the continuous establishment of cross-border entities (Euroregions, Working Communities, Euro-Cities and European Groupings of Territorial Development) (Evrard, 2016; Medeiros, 2011; Perkmann, 2003) along the EU internal and external borders, and transnational entities, not only consolidated by the ongoing 15 transnational INETRREG B programmes, but also by the four existing macro-regional European strategies ${ }^{2}$ (Baltic Sea - 2009, Danube - 2010, Adriatic \& Ionian - 2014 and Alpine - 2015). Indeed, this collected experience in establishing ETC processes, which, in many cases, have been forged for more than two decades, provides a solid scientific background to place the transnational and cross-border territorial levels at the core of EU strategic development and cohesion policies design and implementation.

Finally, the continuous process of EU integration, which 'has been playing a crucial role in protecting and ensuring the stability of democracy on the European continent' (ESPON ATLAS, 2014, p. 94), has also gained from a long experience acquired by EU Member States in coordinating economic (the Euro) border control (Schengen), and other transnational sectoral policies, such as transports and the environment. This means, there is no lack of transnational cooperation experience and administrative capacity to implement our proposed strategy for the ECP post-2020.

\section{Conclusion}

Despite continuous metamorphoses and adaptations to specific socio-economic and political contexts, over its almost 30 years of existence, ECP as stayed tied to its fundamental policy goals of correcting inequalities in several dimensions of territorial cohesion and development. Ultimately, its territorial impacts vary greatly from Member State to Member State and from region to region. In general, less-developed Member States, which absorbed higher volumes of EU funding, have had higher positive impacts, mostly is the socio-economic dimension of territorial cohesion. This might have contributed to reduce the territorial disparities within the EU territory, as proclaimed by several EU Cohesion Reports (EC, 2014). However, rather than an agent of cohesion, ECP has favoured, directly or indirectly, for the most part, the capital cities and the more urbanized and socio-economic dynamic areas within the EU Member States (see Medeiros, 2014a, 2016a, 2016b). In sum, by and large, ECP has had a positive contribution to territorial development all over the EU, but had not led to achieve the goal of territorial cohesion within the EU Member States.

Under this scenario, this article makes a case to place ESP at the heart of the EU policy strategic design, in order to become a decisive factor to perfect the design and impacts of ECP post-2020, notably by leading to an improvement of its effectiveness and efficiency, and ultimately to achieve the goal of territorial cohesion, both at the EU and at the national levels. Furthermore, we suggest a (re)orientation of the ECP rationale towards its initial 
goals of promoting territorial development and cohesion, rather than a more simplified EU policy narrative of 'growth'. Moreover, even though we are aware that ESP is not an EU formal legal competence, we propose that all the efforts made up until now by several EU initiatives which have been promoting it (ESDP, the Territorial Agendas, the INTERREG and the ESPON) are crystalized in an organized and updated EU strategic policy agenda, based on an EU transnational development strategic paradigm.

In accepting this ESP strategic policy framework proposal, the EU would delve more deeply into the EU territorial integration, place-based and smart specialization narratives, which have been adopted by the EC in recent years. Besides, it would prompt a mounting effort to better integrate all territorial levels of spatial planning (EU, transnational, crossborder, national and regional), which have already been triggered by the implementation of ECP in several countries. Furthermore, it would lead to an improvement of coordination in the implementation of sectoral policies with territorial dimension, and also to finally triggering the elaboration of EU cross-border and transnational spatial plans, which are still in an embryonic stage. Another key claim for the advantages for the adoption of such an ESP strategy is that it would most likely induce a change of heart towards an impact-oriented policy monitoring/evaluation process, as opposed to the present ECP result-oriented rationale. This would place TIA procedures at the forefront of EU policy evaluation, which is still in an infancy stage.

To provide a foundation to our claims, we present a simplified 'Spatial Planning Strategic vision for the EU post-2020', and its influence on the strategic design of a post-2020 ECP. More precisely, we suggest a one goal-four targets policy. In concrete terms, the present ECP goals of 'growth and jobs' and 'ETC' would be reduced to a mainstream goal of promoting territorial cohesion and development. This would not imply, however, a reduction of the importance of the ETC programmes. On the contrary, both transnational and cross-border cooperation programmes would be elevated both in policy relevance and in funding allocation, as they would be regarded as adamant ESP processes to foment a more cohesive, harmonious, balanced and integrated EU territory.

Alongside, we propose a new set of guidelines and principles for the post-2020 ECP. Amongst them, we highlight the need to pursue a territorial-driven strategy, where the allocation of EU funds would need to support not only national and regional strategies by means of Operational Programmes, but also transnational and cross-border ones. Add to that, we suggest a stronger focus on large-impact transnational projects and the concentration of investments on anchor cities of less-developed regions, in order to increase the chances of achieving territorial cohesion within the EU and respective Member States.

All these considerations suggest that ESP is an adequate vehicle to promote and achieve, in a more effective and sound way, the goal expressed in the EU Treaty of a more harmonious, cohesive and balanced EU territory, namely by the operationalization of the ECP. Moreover, as pointed out, the EU does not necessarily have to formally place spatial planning as one of its competences, in order to adopt an ESP-based policy development strategy, as ESP visions which are already present in mainstream documents and programmes (ESDP, Territorial Agendas, ESPON and INTERREG) have been integrated over time in the national, regional and also by some transnational (macro-regional and cross-border) strategies in Europe. As such, the incorporation of an ESP vision into the EU policy agenda design would be regarded as a natural additional milestone for this 
recognition of the need to think and act strategically from a transnational territorial perspective.

In a nutshell, our analysis shows that what we regard as the ECP main goal (territorial cohesion) and ESP are similar in intention, thus making a stronger case for marrying them for a common benefit. However, we are well aware that, from a realistic point of view, the present EU political scenario, marked by the Brexit process and increasing nationalist movements, does not favour a transnational approach for a post-2020 ECP. Moreover, as Faludi (2016) eloquently reminds us, there is a fundamental conflict between EU Member States guarding their territoriality and the EC trying to gain influence over the territoriality of EU policies. Despite all these constraints, as the exponential growth of ETC processes in Europe has showed, when there are win-win scenarios for all involved, the nationalistic approaches to policy design and implementation tend to dilute quite rapidly. Moreover, the proposed rationale for a transnational ECP strategy could end up being the most effective recipe to counteract nationalist and populist movements, which could, eventually, put an end to the EU project.

\section{Notes}

1. http://ec.europa.eu/regional_policy/en/

2. http://ec.europa.eu/regional_policy/en/policy/cooperation/macro-regional-strategies/

\section{Acknowledgements}

The author would like to thank the editors of this journal, the two anonymous referees and Professor Andreas Faludi for their invaluable comments made on an earlier version on this paper.

\section{Disclosure statement}

No potential conflict of interest was reported by the authors.

\section{ORCID}

Eduardo Medeiros (D) http://orcid.org/0000-0002-8877-5606

\section{References}

Albrechts, L. (2006). Bridge the gap: From spatial planning to strategic projects. European Planning Studies, 14(10), 1487-1500. doi:10.1080/09654310600852464

Bachtler, J., \& Ferry, M. (2015). Conditionalities and the performance of European structural funds: A principal-agent analysis of control mechanisms in European Union cohesion policy. Regional Studies, 49(8), 1258-1273. doi:10.1080/00343404.2013.821572

Bachtler, J., Polverani, L., Oraz, E. H., Clement, K., \& Tödtling-sch]onhoffer, H. (2009). Ex post evaluation of cohesion policy programmes 2000-2006 co-financed by the ERDF (objective 1 and 2): Management and implementation systems for cohesion policy. Report to the Commission of the European Communities (CEC), Brussels.

Bauer, M. (2008). Organizational change, management reform and EU policy-making. Journal of European Public Policy, 15, 627-647. doi:10.1080/13501760802133138

Begg, I. (2010). Cohesion or confusion: A policy searching for objectives. Journal of European Integration, 32(1), 77-96. doi:10.1080/07036330903375115 
Blom-Hansen, J. (2005). Principals, agents, and the implementation of EU cohesion policy. Journal of European Public Policy, 12(4), 624-648. doi:10.1080/13501760500160136

CoR. (2009). Joint COTER-REGI meeting on the present and future benefits of cohesion policy. Background Note, 6.10.2009, Brussels.

Davies, S., \& Polverari, L. (2011). Financial accountability and European Union cohesion policy. Regional Studies, 45(5), 695-706. doi:10.1080/00343404.2010.529118

Davoudi, S., \& Strange, I. (2007). Conceptions of space and place in strategic spatial planning. London: Routledge.

Dühr, S., Colomb, C., \& Nadin, V. (2010). European spatial planning and territorial cooperation. New York, NY: Routledge.

Durand, F. (2014). Challenges of cross-border spatial planning in the metropolitan regions of Luxembourg and lille. Planning Practice \& Research, 29(2), 113-132. doi:10.1080/02697459. 2014.896148

EC. (1991). Europe 2000: Outlook for the development of the community's territory. Luxemburg: Commission of the European Communities, Directorate-General for Regional Policy.

EC. (1994). Europe 2000+. Cooperation for European territorial development. Luxemburg: Author.

EC. (1997). The EU compendium of spatial planning systems and policies. Luxemburg: Regional Development Studies, Office for Official Publications of the European Communities.

EC. (1999a). European spatial development perspective: Towards a balanced and sustainable development of the territory of the European Union. Luxembourg: Office for Official Publications of the European Communities.

EC. (1999b). MEANS - evaluation socio-economic programmes - evaluating design and management. Vol. 1. Luxembourg: Author.

EC. (2001a). Second report on economic and social cohesion, unity, solidarity, diversity for Europe, its people and its territory. Brussels: Author.

EC. (2001b). European governance. A white paper. COM (2001) 428 final. Brussels: Author.

EC. (2004). Third report on economic and social cohesion, a new partnership for cohesion: Convergence, competitiveness, cooperation. Communication from the Commission COM/2004/ 107. Luxembourg: Office for Official Publications of the European Communities.

EC. (2008a). EU cohesion policy 1988-2008: Investing in Europe's future. Panorama 26, Inforegio, European Union Regional Policy. Brussels: European Commission.

EC. (2008b). Regions 2020. An assessment of future challenges for EU regions. Commission Staff Working Document. Brussels: European Union Regional Policy, European Commission.

EC. (2014). Sixth report on economic, social and territorial cohesion. Investment for jobs and growth. Promoting development and good governance in EU regions and cities. Brussels: Regional and Urban Policy, Author.

ESPON ATLAS. (2006, October). Mapping the structure of the European territory. Federal Office for Building and Regional Planning. Luxembourg: European Spatial Planning Observatory Network.

ESPON ATLAS. (2014, November). Mapping European territorial structures and dynamics. Luxembourg: European Spatial Planning Observatory Network.

EU. (2010). Consolidating versions of the Treaty on European Union and the Treaty on the Functioning of the European Union (2010/C 83/01) EN 30.3.2010 Official Journal of the European Union Volume 53, European Union.

Evrard, E. (2016). The European grouping of territorial cooperation (EGTC): Towards a supraregional scale of governance in the greater region SaarLorLux? Geopolitics, 21(3), 513-537. doi:10. 1080/14650045.2015.1104667

Faludi, A. (2004). Territorial cohesion: Old (French) wine in new bottles? Urban Studies, 41(7), 1349-1365. doi:10.1080/0042098042000214833

Faludi, A. (2006). From European spatial development to territorial cohesion policy. Regional Studies, 40(6), 667-678. doi:10.1080/00343400600868937

Faludi, A. (2010). Cohesion, coherence, cooperation: European spatial planning coming of age? New York, NY: Routledge.

Faludi, A. (2014). EUropeanisation or Europeanisation of spatial planning? Planning Theory \& Practice, 15(2), 155-169. doi:10.1080/14649357.2014.902095 
Faludi, A. (2016). The territoriality of cohesion policy. In S. Piattoni, \& L. Polverani (Eds.), Handbook on cohesion policy in the EU (pp. 491-501). London: Edward Elgar.

Ferrão, J. (2003). A emergência de estratégias transnacionais de ordenamento do território na União Europeia: reimaginar o espaço europeu para criar novas formas de governança territorial? GeoINOVA, 7, 11-37. Retrieved from http://ftp.infoeuropa.eurocid.pt/database/000044001000045000/000044412.pdf

Ferrão, J. (2010). Ordenamento do território: 25 anos de aprendizagem? Europa Novas Fronteiras, Portugal - 25 anos de Integração Europeia, Princípia, 26/27, pp. 77-84.

Kassim, H. (2008). 'Mission impossible', but mission accomplished: The Kinnock reforms and the European Commission. Journal of European Public Policy, 15(5), 648-668. doi:10.1080/ 13501760802133146

Kidd, S., \& Shaw, D. (2013). Reconceptualising territoriality and spatial planning: Insights from the sea. Planning Theory \& Practice, 14(2), 180-197. doi:10.1080/14649357.2013.784348

Kunzmann, K. (2006). The Europeanization of spatial planning. In N. Adams et al. (Eds.), Regional development and spatial planning in an enlarged European Union (pp. 43-63). Aldershot: Ashgate.

McCann, P., \& Ortega-Argilés, R. (2015). Smart specialization, regional growth and applications to European Union cohesion policy. Regional Studies, 49(8), 1291-1302. doi:10.1080/00343404. 2013.799769

Medeiros, E. (2011). (Re)defining the concept of Euroregion. European Planning Studies, 19(1), 141-158. doi:10.1080/09654313.2011.531920

Medeiros, E. (2013). Euro-Meso-Macro: The new regions in Iberian and European space. Regional Studies, 47(8), 249-1266. doi:10.1080/00343404.2011.602336

Medeiros, E. (2014a). Assessing territorial impacts of the EU cohesion policy: The Portuguese case. European Planning Studies, 22(9), 1960-1988. doi:10.1080/09654313.2013.813910

Medeiros, E. (2014b). Assessing territorial impacts of the EU cohesion policy at the regional level: The case of Algarve. Impact Assessment and Project Appraisal, 32(3), 198-212. doi:10.1080/ 14615517.2014.915134

Medeiros, E. (2014c). The Europeanization of spatial planning processes in Portugal within the EU cohesion policy strategies (1989-2013). Geography and Spatial Planning Journal, 6, 201-222. doi:10.17127/got/2014.6.012

Medeiros, E. (2014d). Is there a new TRUST in inner Scandinavia, evidence from cross-border planning and governance. Geografiska Annaler, 96(4), 363-386. doi:10.1111/geob.12057

Medeiros, E. (2016a). European Union cohesion policy and Spain: A territorial impact assessment. Regional Studies. doi:10.1080/00343404.2016.1187719

Medeiros, E. (2016b). EU cohesion policy in Sweden (1995-2013) - A territorial impact assessment. European Structural \& Investment Funds Journal, 3(4), 254-275. http://estif.lexxion.eu/article/ ESTIF/2015/4/8

Medeiros, E. (2016c). Is there a rise of the territorial dimension in EU cohesion policy. Finisterra, 103(2016), 89-113. doi:10.18055/Finis7940

Medeiros, E. (2016d). Territorial cohesion: An European concept. European Journal of Spatial Development, 60. Retrieved from http://www.nordregio.se/Global/EJSD/Refereed articles/ refereed60.pdf

Medeiros, E. (2016e). Territorial impact assessment and public policies: The case of Portugal and the EU. Public Policy Portuguese Journal, 1(1), 51-61. https://gesdoc.uevora.pt/api/pages/file/ \&id $=467488$

Medeiros, E. (2017). Cross-border cooperation in inner Scandinavia: A territorial impact assessment. Environmental Impact Assessment Review, 62(2017), 147-157. doi:10.1016/j.eiar.2016. 09.003

Mendez, C. (2011). The Lisbonization of EU cohesion policy: A successful case of experimentalist governance? European Planning Studies, 19(3), 519-537. doi:10.1080/09654313.2011.548368

Mendez, C. (2013). The post-2013 reform of EU cohesion policy and the place-based narrative. Journal of European Public Policy, 20(5), 639-659. doi:10.1080/13501763.2012.736733

Molle, W. (2007). European cohesion policy. Abingdon: Routledge. 
Moreno, A. (2012). Integration of hydrological and regional and urban planning in Spain. In J. Burian (Ed.), Advances in spatial planning (pp. 331-336). Rijeka: InTech.

Morphet, J. (2011). Effective practice in spatial planning. London: Routledge.

Perkmann, M. (2003). Cross-border regions in Europe - Significance and drivers of regional crossborder co-operation. European and Urban and Regional Studies, 10(2), 153-171. doi:10.1177/ 0969776403010002004

Polverani, L. (2016). The new ambitions for 2014-2020 European structural and investment funds evaluation: Pouring water in a leaking container? European Structural and Investment Funds Journal, 4(2), 59-67. http://estif.lexxion.eu/issue/ESTIF/2016/2

Potter, R., Binns, T., Elliott, J., \& Smith, D. (2008). Geographies of development. An introduction to development studies (3rd ed.). Essex: Pearson Education Limited.

Rodriguez-Pose, A., \& Fratesi, U. (2004). Between development and social policies: The impact of European structural funds in objective 1 regions. Regional Studies, 38(1), 97-113. doi:10.1080/ 00343400310001632226

Solly, A. (2016). Place-based innovation in cohesion policy: Meeting and measuring the challenges. Regional Studies, Regional Science, 3(1), 193-198. doi:10.1080/21681376.2016.1150199

Stutz, B., \& Warf, B. (2012). The world economy. Geography, business, development (6th ed.). New York, NY: Prentice Hall.

Territorial Agenda. (2007). Territorial agenda of the European Union: Towards a more competitive and sustainable Europe of diverse regions. Retrieved from http://www.eu-territorial-agenda.eu/ Reference\%20Documents/Territorial-Agenda-of-the-European-Union-Agreed-on-25-May2007.pdf

Territorial Agenda 2020. (2011). Territorial agenda of the European Union 2020 - Towards an inclusive, smart and sustainable Europe of diverse regions. Retrieved from http://www.eu2011. hu/files/bveu/documents/TA2020.pdf

Thomas, A. (2000). Development as practice in a liberal capitalist world. Journal of International Development, 12, 773-787. doi:10.1002/1099-1328(200008)12:6<773::AID-JID716>3.0.CO;2-7

UNDP. (2001). Human development report, 2001: Promoting linkages. United Nations Development Programme. Oxford: Oxford University Press.

Walsh, C. (2014). Rethinking the spatiality of spatial planning: Methodological territorialism and metageographies. European Planning Studies, 22(2), 306-322. doi:10.1080/09654313.2012. 741568

Waterhout, B. (Ed.). (2008). The institutionalisation of European spatial planning. Sustainable urban areas, $\mathrm{n}^{\circ} 18$. Delft: Delft University of Technology. 